\title{
CHALLENGES OF INDUSTRY 4.0 IN THE VISEGRÁD GROUP
}

\author{
ANDREA ÉLTETő*1 \\ ${ }^{1}$ Centre for Economic and Regional Studies, Institute of World Economics, Tóth Kálmán u. 4, Budapest, \\ 1097, HUNGARY
}

\begin{abstract}
This article provides a snapshot describing the position of the Visegrád Group in terms of adopting Industry 4.0 technologies. Despite being promoted and supported by the state, the introduction of these modern methods is still not as widespread as in other EU member states. The reason for this is the heterogeneity of firms: there are substantial differences between large and small as well as foreign and domestic firms. Statistics, surveys and interviews have proven that foreign-owned, larger companies are front-runners, while smaller domestic ones face considerable financial and technological challenges. However, it is concluded that the main problem is the continued lack of the necessary skilled labour force.
\end{abstract}

Keywords: Industry 4.0, Visegrád Group, Foreign Direct Investment

\section{Introduction}

The term "Industry 4.0" stems from Germany (opening speech of the Hannover Messe in 2011). Industry 4.0 is a complex concept, composed of nine main pillars: robotisation, simulation, the Internet of Things, additive manufacturing, cybersecurity, cloud computing, big data, augmented reality as well as horizontal and vertical system integration. Nowadays, it means a new kind of corporate and production organisation combining physical and digital production.

The concept and application of Industry 4.0 have also been promoted in the Visegrád Group. Industry associations and governmental organisations have launched strategies as well as programmes to inform and help companies; mainly small and medium-sized enterprises (SMEs). In spite of these efforts, statistics show that the Visegrád Group remains underdeveloped in the field of Industry 4.0. [1] This article tries to detect the reasons for this lag by summarising the available statistics and findings concerning this topic.

First, the Organisation for Economic Co-operation and Development (OECD) Information and Communications Technology (ICT) usage data and robotisation data are examined before the results of several surveys concerning the introduction of Industry 4.0 are analysed. Finally, the personal interviews conducted in the Visegrád Group are evaluated. Among the problems and challenges of small domestic companies, it was found that the most important is the human factor, namely the lack of necessary skills and the risk-avoiding managerial mindset.

\footnotetext{
*Correspondence: elteto.andrea@krtk.hu
}

\section{Data on Industry 4.0 in the Visegrad Group}

The OECD "ICT Access and Usage by Businesses" database contains several such elements that can be bound to a functioning Industry 4.0 system. These statistics show to what extent the companies in the given country use certain elements of digitalisation and automation. Compared to all the European Union (EU) member states, the Visegrád Group is situated relatively close to the bottom of the ranking. Naturally, differences according to the indicators and countries are present.

Table 1 shows the relevant figures with regard to the use of some basic digital tools (having a website or highspeed broadband) as well as the share of companies applying big data analytics, cloud computing, additive manufacturing, digital company resources and customer relationship management software. As a "reference country", Germany was included in the table because the concept of Industry 4.0 stems from this country, moreover, business contacts and production chains between the Visegrád Group and Germany are highly significant. (It must be noted that although the performance of Germany is good, its indicators are not always the best among the EU member states.)

The table shows three phenomena. Firstly, in the selected areas, Slovakia and Hungary are the weak performers and the Czech Republic is the best in the Visegrád Group. Secondly, Germany performs much better than the Visegrád Group in all fields. Thirdly, although the use of 3D printing and Enterprise Resource Planning (ERP) software in every country is more widespread with regard 
Table 1: Selected indicators of Industry 4.0 for manufacturing sectors compared to all sectors in 2020 as a \% of all companies (Source: OECD ICT Access and Usage by Businesses database)

\begin{tabular}{l|ll|ll}
\hline & Poland & \multicolumn{2}{l}{ Czech Republic } \\
\hline Sector & All & Man. & All & Man. \\
\hline Website & 71.32 & 77.13 & 83.32 & 85.02 \\
Broadband & 42.77 & 38.47 & 34.44 & 28.99 \\
ERP* & 28.54 & 32.48 & 38 & 48.36 \\
CRM* $^{*}$ & 30.92 & 20.91 & 20.86 & 20.19 \\
Cloud Comp. & 24.42 & 23.06 & 28.89 & 26.52 \\
Big Data & 8.47 & 6.51 & 9.12 & 7.98 \\
3D printing & 3.42 & 7.56 & 6.25 & 12.89 \\
ICT training & 17.75 & 16.14 & 24.74 & 27.6 \\
\hline \multicolumn{5}{|l|}{ Hungary } \\
\hline \multicolumn{5}{|l|ll}{} \\
\hline Sector & Slovakia & Man. & All & Man. \\
\hline Website & 75.82 & 75.22 & 63.23 & 72.96 \\
Broadband & 32.12 & 27.45 & 35.77 & 31.11 \\
ERP* & 31.12 & 38.11 & 14.33 & 20.41 \\
CRM* & 22.19 & 20.88 & 12.10 & 11.44 \\
Cloud Comp. & 25.57 & 24.2 & 25.21 & 23.17 \\
Big Data & 5.6 & 3.93 & 6.99 & 7.12 \\
3D printing & 3.89 & 7.99 & 3.4 & 6.78 \\
ICT training & 16.18 & 17.83 & 15.97 & 17.25 \\
\hline
\end{tabular}

\begin{tabular}{l|ll}
\hline & \multicolumn{2}{|l}{ Germany } \\
\hline Sector & All & Man. \\
\hline Website & 88.35 & 92.52 \\
Broadband & 44.86 & 40.38 \\
ERP* & 29.26 & 50.33 \\
CRM $^{*}$ & 44.21 & 47.15 \\
Cloud Comp. & 33.32 & 30.71 \\
Big Data & 17.83 & 12.25 \\
3D printing & 7.35 & 18.02 \\
ICT training & 23.76 & 26.58 \\
\hline
\end{tabular}

*Data for Businesses using Enterprise Resource Planning (ERP) and Customer Relationship Management (CRM) software are from 2019

- Man.: Manufacturing

- Website: businesses with a website or home page

- Broadband: Businesses with a broadband download speed of at least $100 \mathrm{Mbps}$

- Cloud Computing: Businesses purchasing cloud computing services

- Big Data: Businesses implementing big data analytics

- 3D printing: Businesses using 3D printing technology

- ICT training: Businesses that have provided any type of training to develop the ICT-related skills of their employees within the last 12 months.

to manufacturing than the average, in other areas no significant sectoral difference is found. Around $16-25 \%$ of companies within the Visegrád Group provided some kind of ICT training to their employees in the previous year.

In the database, data are also classified according to
Table 2: Selected percentage indicators of Industry 4.0 for large and medium-sized enterprises in 2020 (Source: OECD ICT Access and Usage by Businesses database)

\begin{tabular}{|c|c|c|c|c|}
\hline & \multicolumn{2}{|l|}{ Poland } & \multicolumn{2}{|c|}{ Czech Republic } \\
\hline Company size & Large & Medium & Large & Medium \\
\hline Website & 92.49 & 88.64 & 93.47 & 90.52 \\
\hline Broadband & 69.4 & 52.17 & 55.44 & 38.5 \\
\hline ERP/2019 & 87.27 & 53.87 & 87.02 & 68.05 \\
\hline CRM/2019 & 79.66 & 52.47 & 46.33 & 35.19 \\
\hline Cloud comp. & 59.55 & 37.68 & 55.63 & 36.88 \\
\hline Big data & 28.37 & 12.76 & 24.75 & 13.5 \\
\hline 3D printing & 17.39 & 6.28 & 25.83 & 10.35 \\
\hline \multirow[t]{2}{*}{ ICT training } & 71.02 & 32.67 & 77.22 & 43.96 \\
\hline & \multicolumn{2}{|c|}{ Slovakia } & \multicolumn{2}{|c|}{ Hungary } \\
\hline Company size & Large & Medium & Large & Medium \\
\hline Website & 88.84 & 79.66 & 86.24 & 78.05 \\
\hline Broadband & 41.39 & 33.62 & 55.27 & 40.46 \\
\hline ERP/2019 & 72.24 & 47.95 & 62.03 & 31.97 \\
\hline CRM/2019 & 48.34 & 33.9 & 34.44 & 21.91 \\
\hline Cloud comp. & 50.62 & 33.28 & 58.83 & 36.75 \\
\hline Big data & 16.7 & 7.71 & 19.28 & 10.69 \\
\hline 3D printing & 17.79 & 5.43 & 14.67 & 4.65 \\
\hline ICT training & 62.19 & 32.84 & 65.45 & 30.64 \\
\hline & \multicolumn{2}{|c|}{ Germany } & & \\
\hline Company size & Large & Medium & & \\
\hline Website & 97.17 & 93.16 & & \\
\hline Broadband & 73.41 & 54.16 & & \\
\hline ERP/2019 & 77.35 & 55.62 & & \\
\hline CRM/2019 & 68.15 & 58.28 & & \\
\hline Cloud comp. & 62.05 & 41.18 & & \\
\hline Big data & 35.81 & 22.23 & & \\
\hline $3 \mathrm{D}$ printing & 23.2 & 11.55 & & \\
\hline ICT training & 73.07 & 43.22 & & \\
\hline
\end{tabular}

the size of the company. As is presented in Table 2, it is salient that large firms are by far the best, not only compared to small ones but also compared to medium-sized firms. This is true of Germany as well, although differences here are smaller than in the case of companies from the Visegrád Group. As for the countries from the Visegrád Group that have been integrated into the global supply chains and host affiliates of large multinational enterprises (MNEs) [2], these data, which is later underlined by surveys, show that the application of Industry 4.0 is most advanced at large foreign companies. Therefore, Industry 4.0 reinforces duality among local firms and the dependency on foreign capital (Foreign Direct Investment (FDI) led development model) in the Visegrád Group. [1]

With the reduction in the price of robots, automation has gained momentum worldwide. Even though the Visegrád Group has rapidly increased its stock of industrial robots, it is still overshadowed by the level of Germany. The robot densities of the given countries are 


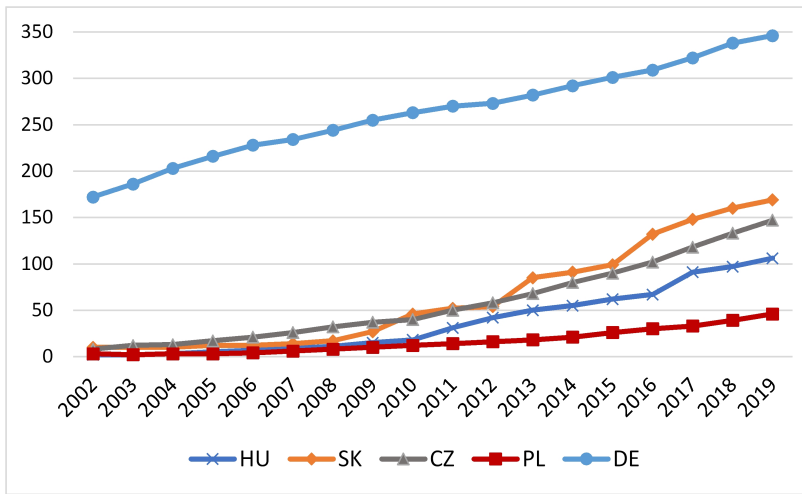

Figure 1: Robot density (No. of multipurpose industrial robots per 10,000 employees) in the manufacturing sector (Source: International Federation of Robotics)

shown in Fig. 1. It can be seen that this indicator is the lowest in Poland and the highest in Slovakia. According to the International Federation of Robotics, the automotive industry is the largest customer of robots, followed by the electrical/electronics sector, which is also true of the economies in the Visegrád Group. The automotive industry plays the biggest role in the Czech Republic, Slovakia and Hungary in the region, moreover, robotisation is more advanced in these economies.

\section{Experiences according to surveys and interviews}

With the spread of the Industry 4.0 concept, several surveys have been conducted among companies in the Visegrád Group concerning the introduction of these technologies as well as the opportunities, barriers and challenges they present. The main findings of these surveys were grouped according to certain areas of concern and the literature references are provided at the end.

Introduction of Industry 4.0 The Visegrád Group is less prepared for Industry 4.0 than Western European economies. Generally, it is an important feature of this region that the main actors of Industry 4.0 are foreign companies, mostly multinationals. Based on international indices as well as rankings of governance, technology and entrepreneurial competences, the Czech Republic and Hungary performed better than the other two countries. [3,4]

The readiness of domestic firms Given that domestic companies usually do not have strategies, a fear of taking risks is present. Managerial attitude and capability is often inadequate. The activity and knowledge of domestic firms with regard to Industry 4.0 are relatively weak, sometimes even perceiving it as a threat. However, as time passes, the domestic companies have become more confident and started to apply the new technologies of Industry 4.0. [5-14]

Opportunities for domestic firms It is beneficial that Industry 4.0 tools detect organisational weaknesses.
Opportunities stemming from Industry 4.0 are different for SMEs and MNEs. Companies are rethinking their pricing strategies by making it more sophisticated and room for price setting is growing. [15-18]

Challenges and problems Automation in many cases was induced by labour shortages and the obsolete production technologies that were available. Data storage and security is a challenge as companies do not want to share their data with business partners. The shortage of skilled labour is acute. Production complexity and customer requirements have increased. The compatibility of new technologies is problematic and information on them is insufficient. There is a lack of financial resources for introducing Industry 4.0 technologies at SMEs. The corporate culture in domestic companies needs to change. [14, 19-22]

Production control and organisation In the Visegrád Group, since robotization relies on the localization decisions of MNEs and is mainly based on the automotive industry, it is "robotisation-dependent." Competition as well as the lower cost and better quality of robots encourage automation. At some companies, functional upgrading is taking place but the structure of value creation remains, that is, no specialisation occurs in terms of advanced activities and higher value added per unit. [19,23]

In a study from 2020 [24], interviews were completed with experts from the business and academic fields. In Poland, Hungary, the Czech Republic and Slovakia, 16, 13,6 , and 6 interviews were conducted in person, over the phone or online, respectively. Although this sample is relatively small, different institutions, companies and agencies were questioned so the opinions of various groups were gathered. Table 3 shows the essence of these opinions concerning the aforementioned topics.

\section{Discussion}

The described surveys and interviews show that the perception as well as maturity of Industry 4.0 vary among firms in the Visegrád Group. Some companies are just beginning to contemplate such technologies, while others already regard them as necessary. Over the past decade, "Industry 4.0 awareness" has clearly developed. A lot depends on the managerial mindset. Contrary to foreign firms, a constant development culture in domestic firms is often lacking, therefore, risks and novelties are avoided. However, a change in generation is occurring at many firms, the retirement of old owners is bringing about new possibilities. Once a plan or strategy to implement Industry 4.0 has been drawn up, preparation, piloting and testing are important. Adaptation can be time-consuming, moreover, the investment can take as long as two years 
Table 3: Industry 4.0 in the Visegrád Group - issues raised during the interviews (Source: own compilation from the interviews conducted as part of the study [24])

\begin{tabular}{ll}
\hline Topic & Opinions from the interviews \\
\hline $\begin{array}{l}\text { Introduction } \\
\text { of Industry } \\
4.0\end{array}$ & $\begin{array}{l}\text { Primarily foreign firms apply for } \\
\text { these technologies }\end{array}$ \\
\hline $\begin{array}{l}\text { Readiness } \\
\text { of domestic } \\
\text { firms }\end{array}$ & $\begin{array}{l}\text { Poor and lagging. The degree of } \\
\text { innovation is low, few enterprises } \\
\text { have a plan or strategy. }\end{array}$ \\
\hline $\begin{array}{l}\text { Opportunities } \\
\text { for domestic }\end{array}$ & $\begin{array}{l}\text { Mental adjustment at the executive } \\
\text { level is necessary. A change in gen- } \\
\text { firms }\end{array}$ \\
\hline $\begin{array}{l}\text { Challenges } \\
\text { and problems }\end{array}$ & $\begin{array}{l}\text { Long-term and expensive invest- } \\
\text { ment with delayed benefits. In- } \\
\text { adequate education system. Skills }\end{array}$ \\
& $\begin{array}{l}\text { needed; managerial capabilities are } \\
\text { mostly weak and brain drain. }\end{array}$ \\
\hline $\begin{array}{l}\text { Production } \\
\text { control and } \\
\text { organisation }\end{array}$ & $\begin{array}{l}\text { MNE headquarters usually retain } \\
\text { the know-how and R\&D, Industry } \\
\text { 4.0 gives more power to MNEs, de- } \\
\text { cisions about its usage are made lo- }\end{array}$ \\
& $\begin{array}{l}\text { cally by the management of the sub- } \\
\text { sidiaries. }\end{array}$ \\
\hline
\end{tabular}

to be implemented, leading to results only materialising later.

The results of surveys and interviews support the statistics, proving a duality among firms from the Visegrád Group: large, mostly foreign companies perform much better than smaller domestic firms. The interviews confirmed that business models as well as cooperation between foreign headquarters and local subsidiaries will be changed due to Industry 4.0 technologies. Although multinational enterprise (MNEs) develop R\&D on their own, they partly share their results with local subsidiaries. Decisions about the usage of Industry 4.0-related technologies are mostly made by the management of local subsidiaries. For the successful functioning of a production chain, the absorptive capacity and collaboration of the subsidiaries are essential.

Several challenges of and barriers to Industry 4.0 for domestic SMEs were presented, which can be grouped into technological, financial and human factors. In my opinion, the problem of the human labour force is the most difficult to surmount. Data from Eurostat show that the number of graduates per thousand inhabitants in science, technology, engineering, mathematics and computing is only $60 \%$ of the EU average in Hungary and Slovakia, $80 \%$ in the Czech Republic and $96 \%$ in Poland. ${ }^{\dagger}$ A considerable proportion of these graduates later work abroad, diminishing the skilled workforce in the home countries.

Industry 4.0 is changing the characteristics of human capital, decreasing the labour intensity of certain produc-

\footnotetext{
${ }^{\dagger}$ Eurostat (educ_uoe_grad04).
}

tion phases. Those jobs that cannot or can hardly be automated require creativity, social intelligence and high cognitive abilities. The risk of unemployment is less with better education indicators (logic, mathematics, reading comprehension). [25] Suitable competencies in an Industry 4.0 world are the ability to learn, cooperation, flexibility, problem-solving, creativity and also non-cognitive skills. [26] These competencies - that should have already been developed at primary school - facilitate retainment, which has become critical in this rapidly changing technological environment, not to mention during a pandemic. At present, the education systems in the Visegrád Group do not strengthen these competencies and any reforms only bring about results in the long run.

\section{Conclusion}

Regarding several elements of the complex technologies of Industry 4.0, the statistics show the slowness of the Visegrád Group to adopt them compared not only to Germany but also to other semi-periphery EU member states. However, the statistics on automation (robot density in manufacturing) demonstrate that rapid development has taken place especially in Slovakia, the Czech Republic and Hungary. This contradiction can be explained by the fact that automation is driven mostly by the automotive industry, while in the other statistics the characteristics of all sectors are reflected. The statistics for an entire country also cover the differences between large and small as well as foreign and domestic companies. Large and foreign companies are much more advanced in terms of applying Industry 4.0 technologies in the Visegrád Group.

Despite government incentives and programmes, domestic firms are in general less willing to introduce new technologies, e.g., few of them have a strategy for implementing Industry 4.0, however, a learning process is present. Traditional corporate culture, obsolete technologies and the lack of financial resources are important challenges for a small or medium-sized firm. The major barrier, however, is that the bulk of the human labour force lacks the proper skills and competencies to meet the demands of Industry 4.0. Since the present education system is not ready to deal with this problem, huge and rapid changes in this regard cannot be expected.

\section{REFERENCES}

[1] Éltetô, A.; Sass, M.: A kapitalizmus változatai és az ipar 4.0 a visegrádi országokban. Közgazdasági Szemle, 2021, 68(5), 490-514 DOI: 10.18414/KSZ.2021.5.490

[2] Sass, M.: FDI-based models in the Visegrád countries and what the future may have in store for them, wiiw Monthly Report 2021/02, Vienna, wiiw, pp. 18-26

[3] Naudé, W.; Surdej, A.; Cameron, M.: The Past and Future of Manufacturing in Central and Eastern Europe: Ready for Industry 4.0? IZA Discussion Paper, 2019, 12141 http://hdl.handle.net/10419/196639 
[4] Szabó, S.: Transition to Industry 4.0 in the Visegrád Countries. European Economy Economic Brief 052, Brussels, European Commission, 2020.

[5] Nagy, J.; Oláh, J.; Erdei, E.; Máté, D.; Popp, J.: The Role and Impact of Industry 4.0 and the Internet of Things on the Business Strategy of the Value Chain-The Case of Hungary. Sustainability, 2018, 10, 3491 DOI: 10.3390/su10103491

[6] Nick, G.: Az Ipar 4.0 hazai adaptációjának kihívásai a vállalati és területi összefüggések tükrében. $P h D$ Dissertation, 2018.

[7] Stasiak-Betlejewska, R.; Luminita, P.; Glin, W.: The Influence of Industry 4.0 on the Enterprise Competitiveness. Multidisciplinary Aspects of Production Engineering, 2018, 1, 641-648 DOI: 10.2478/mape2018-0081

[8] Adamik, A.; Novicki, M.: Preparedness of Companies for Digital Transformation and Creating a Competitive Advantage in the Age of Industry 4.0. Proceedings of the International Conference on Business Excellence, 2018, 12(1), 10-24 DOI: 10.2478/picbe-2018-0003

[9] Gryzb, K.: Industry 4.0 Market in Poland from the International Perspective. Hradec Economic Discussion Papers, 2019, 9, 252-262 DOI: 10.36689/uhk/hed/2019-01-025

[10] Mohelska, H.; Sokolova, M.: Management Approaches for Industry 4.0 - the Organizational Culture Perspective. Technological and Economic Development of Economy, 2018, 24(6), 2225-2240. DOI: 10.3846/tede.2018.6397

[11] Vrchota, J.; Volek, T.; Novotná, M.: Factors Introducing Industry 4.0 to SMEs. Soc. Sci., 2019, 8(5), 130 DOI: $10.3390 /$ socsci 8050130

[12] Grenciková, A.; Kordos, M.; Sokol, J.: The Approach to Industry 4.0 within the Slovak Business Environment. Soc. Sci., 2019, 8(4), 104. DOI: 10.3390/SOCSCI8040104

[13] Soukupová, N.; Adamová, M.; Krninská, R.: Industry 4.0: An Employee Perception (Case of the Czech Republic). Acta Universitatis Agriculturaevet Silviculturae Mendelianae Brunensis, 2020, 68, 637644 DOI: 10.11118/actaun202068030637

[14] Obermayer, N.; Csizmadia, T.; Hargitai, D. M.; Kígyós, T. A.: Az Ipar 4.0. implementációval kapcsolatos vezetôi motivációk és akadályozó tényezők elemzése hazai vállalatvezetôk véleménye alapján. Vezetéstudomány/Budapest Management Review, 2021, 52(2), 60-72 DOI: 10.14267/VEZTUD.2021.02.06

[15] Halmosi, P.: A technológiaorientált start-up cégek lehetôségei és korlátai az ipar 4.0 korszakában - kérdőíves felmérés alapján / The possibilities and limits of technology-oriented start-ups under Industry 4.0 - a survey-based study. Vezetéstudomány/Budapest Management Review, 2019, 50(9), 40-48 DOI: 10.14267/VEZTUD.2019.09.05

[16] Horváth, D.; Szabó, R. Z.; Driving forces and barriers of Industry 4.0: Do multinational and small and medium-sized companies have equal opportunities? Technological Forecasting and Social Change, 2019, 146, 116-132 DOI: 10.1016/j.techfore.2019.05.021

[17] Rekettye, G.: Az ipar 4.0 hatása az árakra és a vállalati árképzés gyakorlatára $=$ The effects of industry 4.0 on prices and price settings. Vezetéstudomány / Budapest Management Review, 2020, 51(4), 15-25 DOI: 10.14267/VEZTUD.2020.04.02

[18] Szabó, R. Z.; Horváth, D.; Hortoványi, L.: Hálózati tanulás az ipar 4.0 korában. Közgazdasági Szemle, 2019, 66, 72-94 DOI: 10.18414/KSZ.2019.1.72

[19] Szalavetz, A.: Digital transformation and local manufacturing subsidiaries in central and eastern Europe: Changing prospects for upgrading? The challenge of digital transformation in the automotive industry, Brussels, ETUI, 47-64, 2020.

[20] Nagy, J.: Az ipar 4.0 fogalma és kritikus kérdései - vállalati interjúk alapján. Vezetéstudomány / Budapest Management Review, 2019, 50(1), 14-26 DOI: 10.14267/VEZTUD.2019.01.02

[21] Papula, J.; Kohnová, L.; Papulová, Z.; Suchoba, M.: Industry 4.0: Preparation of Slovak Companies, the Comparative Study. Smart Technology Trends in Industrial and Business Management, New York, Springer International Publishing, 101-114, 2019.

[22] Slusarczyk, B.: Industry 4.0: are we ready? Polish Journal of Management Studies, 2018, 17, 232-248 DOI: 10.17512/PJMS.2018.17.1.19

[23] Cséfalvay, Z.: Robotization in Central and Eastern Europe: catching up or dependence? European Planning Studies, 2020, 28(8), 1534-1553 DOI: 10.1080/09654313.2019.1694647

[24] Götz, M.; Éltetô, A.; Sass, M.; Vlcková, J.; Zacharová, A.; Ferenciková, S.; Bic, J.; Kaczkowska-Serafinska, M.: Effects of Industry 4.0 on FDI in the Visegrád countries. Final report. Vistula University, Supported by the International Visegrad Fund, 2020.

[25] Nedelkoska, L.; Quintini, G.: Automation, skills use and training, OECD Social, Employment and Migration Working Papers, 2018, 202 DOI: 10.1787/1815199X

[26] Pató, G.; Kovács, K.; Abonyi, J.: A negyedik ipari forradalom hatása a kompetenciacserélődésre. Vezetéstudomány / Budapest Management Review, 2021, 52(1), 56-70 DOI: 10.14267/VEZTUD.2021.1.05 